\title{
Oxidative stress and premature senescence in corneal endothelium following penetrating keratoplasty in an animal model
}

Xiaowen Zhao ${ }^{1}$, Ye Wang ${ }^{1,2^{*}}$, Yao Wang ${ }^{1}$, Suxia Li $i^{1}$ and Peng Chen ${ }^{1}$

\begin{abstract}
Background: The purpose of this study was to address the question of how the premature senescence process may affect corneal endothelium after penetrating keratoplasty, because the quality of donor corneal endothelial cells is important for corneal transplant success.
\end{abstract}

Methods: The cell senescence and induced oxidative stress in corneal endothelium were assessed using a normalrisk orthotopic mice corneal transplantation model. Senescence associated beta-galactosidase (SA-beta-Gal) staining was used to evaluate premature senescence in the endothelium of corneal allografts. Oxidative Stress and Antioxidant Defense $\mathrm{RT}^{2}$-PCR Arrays and in vitro experimental model using $\mathrm{H}_{2} \mathrm{O}_{2}$ treatment were used to investigate the possible mechanism.

Results: SA-beta-Gal positivity was observed obviously in mice corneal endothelium of allogenic group and the levels of p16 ${ }^{\text {INK4a }}$ message and protein increased in endothelium of allogenic group compared to syngenic group. By PCR array, an oxidant-antioxidant imbalance was found in the endothelium of corneal allograft after PKP. The results from mice model were validated using human endothelium samples of corneal allograft after PKP. We also developed an in vitro experimental model using $\mathrm{H}_{2} \mathrm{O}_{2}$ treatment to simulate a state of oxidative stress in cultured human corneal endothelial cells (HCECs) and found that elevated ROS levels, the up-regulation of CDK inhibitors and ROS-mediated p16 $6^{\text {INK4A }}$ up-regulation in HCECs occur via the ASK1-p38 MAPK pathway.

Conclusions: Our results demonstrate the presence of oxidative stress and premature senescence in the endothelium of corneal allografts following PKP.

Keywords: Oxidative stress, Premature senescence, Corneal endothelium, Penetrating keratoplasty

\section{Background}

Human corneal endothelial cells (HCECs) form a monolayer with limited regenerative potential, and these cells maintain stromal dehydration via an ion pump mechanism [1]. For the past 50 years, penetrating keratoplasty (PKP) has been the standard treatment for corneal endothelial specific dysfunctional diseases [2]. Rather than replacing the entire cornea, endothelial keratoplasty

\footnotetext{
* Correspondence: wye112002@126.com

'State Key Laboratory Cultivation Base, Shandong Provincial Key Laboratory of Ophthalmology, Shandong Eye Institute, Shandong Academy of medical Sciences, No. 5 Yanerdao Rd, Qingdao 266071, China

${ }^{2}$ Current affiliation: Central Laboratory of the Second Affiliated Hospital, Medical College of Qingdao University, Qingdao 266042, China
}

(EK) replaces the patient's endothelium with a transplanted disc of posterior stroma/Descemets/endothelium (DSEK) or Descemets/endothelium (DMEK) [3]. This relatively new procedure has revolutionized treatment of disorders of the endothelium. Additionally, lamellar keratoplasty (LKP) replaces only the diseased Bowman's layer and the anterior, or upper part of the corneal stroma with donor material. The quality of donor corneal endothelial cells is very important for corneal transplant success. It was reported that the status of donor endothelial cells may be a necessary condition for graft transparency and long-term survival $[4,5]$. Endothelial cell loss can lead to corneal opacity over 
time after PKP and is substantial 5 years postkeratoplasty [6]. However, there is currently little understanding of the mechanisms of the accelerated postoperative loss of endothelial cells.

DNA breaks and oxidative lesions caused by environmental insults, genetic defects, or endogenous processes belong to certain types of DNA damage. One of the critical effects of oxidative stress caused by reactive oxygen species is the induction of cellular senescence [7, 8]. Numerous studies have reported that premature senescence is closely related to organ transplant [9-12], such as renal transplantation [13]. Cellular senescence is a state of irreversible growth arrest. It can be triggered by many kinds of oncogenic or stressful stimuli including telomere shortening, the epigenetic derepression of the INK4a/ARF locus $[8,14]$. Studies with clinical outcome of HCECs showed the exhibition signs of oxidative DNA damage and that oxidative stress affects the proliferative capacity of HCECs $[15,16]$. These authors also observed that, with respect to the senescence of corneal endothelial cells, age-related relative proliferative capacity and senescence characteristics are not due to replicative senescence caused by critically short telomeres in vitro [17].

Studies have indicated that protein kinase activities are redox-sensitive because key cysteine residues in these proteins can undergo post-translational modifications by oxidants [18]. Several signal transduction pathways have been implicated in cell senescence and cell death, including p38 MAPK pathway. Moreover, apoptosis signal-regulating kinase 1 (ASK1) is a key element in the mechanism of stress-induced cell senescence [19]. It was reported that stress-activated ASK1 accelerates endothelial cell senescence in patients with diabetes [20] and that the inhibition of the ASK1-p38 MAPK pathway could be useful for preventing vascular ageing and for treating neurodegenerative and cardiac diseases [18, 21]. However, whether ASK1-p38 MAPK pathway underlying the cell premature senescence in pathogenesis of corneal endothelium after PKP are not well understood.

In this study, we assessed premature senescence and induced oxidative stress in corneal endothelium using a normal-risk orthotopic mice corneal transplantation model. Then, using an oxidative stress and antioxidant defense PCR array, an oxidant-antioxidant imbalance was found to be involved in the endothelium of corneal allograft after PKP. Next, we validated our results from the mice model using human endothelium samples of corneal allograft after PKP. We also developed an in vitro experimental model using $\mathrm{H}_{2} \mathrm{O}_{2}$ treatment to simulate a state of oxidative stress in cultured HCECs and found that elevated ROS levels, the up-regulation of CDK inhibitors and ROS-mediated p16 ${ }^{\mathrm{INK} 4 \mathrm{~A}}$ upregulation in HCECs occur via the ASK1-p38 MAPK pathway.

\section{Methods}

\section{Animals and the normal-risk orthotopic corneal transplantation}

The study was approved by the Institutional Animal Care Committee of Shandong Eye Institute, and all of the procedures were performed according to the Association for Research and Vision in Ophthalmology (ARVO) Statement for the Use of Animals in Ophthalmic and Vision Research. Six- to eight-week-old adult $\mathrm{BALB} / \mathrm{c}(\mathrm{H}-2 \mathrm{~d})$ mice and C57BL/6 (H-2b) mice, weighing 18 to $20 \mathrm{~g}$, were obtained from the Institute of Zoology Chinese Academy of Sciences. The mice were divided into two groups, syngenic groups and allogenic, each containing 20 mice. The corneal transplantations were performed as previously described [22]. Male C57BL/6 mice were used as donors, and same-aged male $\mathrm{BALB} / \mathrm{c}$ mice were used as recipients. The outcomes of the procedure were compared between syngeneic grafts for which male BALB/c mice were used as both the donors and recipients. Immunosuppressive drugs were not used, either topically or systemically. Only the right eye of each mouse was used for the corneal transplantation; the left eye was undisturbed.

The corneal grafts were collected 4.5 months postgrafting, and the corneal endothelium samples were separated from the grafts. For the PCR Array analysis (SABiosciences Corp., Frederick, MD), the samples were pooled into 6 groups (SP1, SP2, SP3, AP1, AP2, and AP3). Each group comprised three corneal endothelium samples. For the Western blot analyses, the samples were pooled into 6 groups (SW1, SW2, SW3, AW1, AW2, and AW3). Each group comprised two corneal endothelium samples.

\section{Clinical evaluation of grafted mouse corneas, dual staining of corneal endothelium with trypan blue and alizarin red $\mathrm{S}$, and immunohistochemistry}

The mouse corneal grafts were examined once per week for two weeks with a slit-lamp biomicroscope (Haag-Streit model BQ-900, Switzerland). Graft opacity was scored using a scale of one to five, as previously described [22]. The corneal grafts were considered to be failures after receiving two successive scores of 3 . All of the examinations were performed by two blinded observers. The corneal endothelium was examined by dual staining of the corneal endothelium with trypan blue and alizarin red S (SigmaAldrich, Shanghai, China) [23]. For the immunohistochemical analysis of 8-hydroxydeoxyguanosine (8-OHdG) (AB5830; Millipore, Bedford, MA), the corneal samples were fixed in cold methanol and the samples were subjected to staining using the EliVision ${ }^{\text {TM }}$ plus kit (Maxim Corp, Fuzhou, China), according to the manufacturer's protocol, and observed using a Fluorescence E800 microscope (Nikon, Tokyo, Japan). 


\section{Real time PCR-based array analysis}

Total RNA of mouse corneal endothelium was isolated using NucleoSpin RNA II System (Macherey-Nagel, Düren, Germany) according to the manufacturer's instructions. The first-strand cDNA was synthesized from equal amounts of total RNA $(1 \mu \mathrm{g} / \mu \mathrm{l})$ using a PrimeScript ${ }^{\circ} 1$ st Strand cDNA Synthesis Kit (TaKaRa, Dalian, China). The real-time PCR array and data analyses were performed using a $\mathrm{RT}^{2}$ Profiler $^{\mathrm{m}} \mathrm{PCR}$ Array Mouse Oxidative Stress and Antioxidant Defense PCR Array (PAMM-065A, SABiosciences Corp., Frederick, MD).

\section{Patient tissue sample collection}

After obtaining approval from the Shandong Eye Institute ethics committee and according to the tenets of the Declaration of Helsinki, between December 2005 and December 2010, 15 fresh dysfunctional corneal buttons (7.25 to $8 \mathrm{~mm}$ diameter) were collected prospectively from patients with failed corneal transplants. After further sample preparation, five samples were selected for analysis as shown in Table 1 . The prospectively enrolled patients from which dysfunctional corneal buttons were obtained provided written informed consent.

Sex-matched normal human cornea samples from organ donors were provided by the International Federation of Eye Banks at the Eye Bank of Shandong, China (Qingdao, China) and were used as controls. Three samples were used for the SA- $\beta$-Gal staining (age 21, 25, and 19 years) and four samples were used for the gene expression profiling (age 21, 27, 30 and 31 years). Another five samples (three for 22 years old and two for 25 years old) were used to the HECEs culture. Corneal rims, residual parts dissected from donor corneas by a circular trephine in penetrating keratoplasty, were immediately collected for this study as shown in Table 2 . All samples were maintained in corneal storage medium (Optisol; Chiron Ophthalmics, Inc., Irvine, $\mathrm{CA}$ ) at $4{ }^{\circ} \mathrm{C}$ until immediately before the experiment.

\section{RNA extraction and gene expression profiling study}

Total RNA was isolated using the NucleoSpin RNA II System (Macherey-Nagel, Duren, Germany), and firststrand cDNA was synthesized using a MMLV Reverse
Transcriptase 1st-Strand cDNA Synthesis Kit (Epicentre Biotechnologies, Madison, WI) according to the manufacturer's protocol. The gene expression profiling study, including labeling, hybridization, scanning, normalization, and data analysis, was performed by KangChen Bio-tech (Shanghai, China) using a Human Genome Oligo Microarray $(4 \times 44 K$, Agilent Technologies, Palo Alto, CA).

\section{Human corneal endothelial cells (HCECs) culture and treatment}

Five corneal rims samples from normal donor corneas (three for 22 years old and two for 25 years old) were used to the HCECs culture and cell culture was performed by Wuhan PriCells Biomedical Technology Co., Ltd. (Wuhan, China) according to described protocols [8]. Briefly, Descemet's membrane with intact endothelium was carefully dissected in small strips and then incubated in OptiMEM-I supplemented with 10 \% FBS overnight to stabilize the cells before culture. After centrifugation, the strips were incubated in $0.02 \%$ EDTA solution at $37{ }^{\circ} \mathrm{C}$ for 1 hour and cells were resuspended in culture medium containing OptiMEM-I, 8 \% FBS, $5 \mathrm{ng} / \mathrm{mL}$ EGF, $20 \mathrm{ng} / \mathrm{mL}$ NGF, $100 \mathrm{~g} / \mathrm{mL}$ pituitary extract, $20 \mathrm{~g} / \mathrm{mL}$ ascorbic acid, $200 \mathrm{mg} / \mathrm{L}$ calcium chloride, $0.08 \%$ chondroitin sulfate, $50 \mathrm{~g} / \mathrm{mL}$ gentamicin, and antibiotic/antimycotic solution diluted 1/100. Cultures were then incubated at $37{ }^{\circ} \mathrm{C}$ in a $5 \%$ carbon dioxide, humidified atmosphere.

The cultured HCECs were then subjected to various $\mathrm{H}_{2} \mathrm{O}_{2}$ concentrations (0 to $\left.100 \mu \mathrm{M}\right)$ for variable time periods ( 0 minutes, 1 hours, 2 hours and 6 hours) at $37{ }^{\circ} \mathrm{C}$. The cells with no $\mathrm{H}_{2} \mathrm{O}_{2}$ treatment were used as controls. In addition, HCECs were also treated with SB203580 $(10 \mu \mathrm{M})$ (Cell Signaling Technology, Inc., Danvers, MA) and the cells with no SB203580 treatment were used as controls.

\section{Senescence-associated $\beta$-galactosidase (SA- $\beta$-Gal) activity staining}

Following the methods of previous reports [24, 25], human corneal whole mounts were fixed with $4 \%$ formaldehyde (with the endothelial cell side up). The tissues were then incubated at $37^{\circ} \mathrm{C}$ overnight using a

Table 1 The information of all the patients

\begin{tabular}{llllll}
\hline Patient No. & Age/Gender & Affected Eye & History of Ocular Diseases & Timea (years) & Experiment \\
\hline 1 & 41/M & OS & Keratoplasty for corneal opacity & 5 & SA- $\beta$-Gal staining \\
2 & 35/M & OS & Keratoplasty for corneal opacity & 8.5 & SA- $\beta$-Gal staining \\
3 & 62/M & OD & Keratoplastyfor bullous keratopathy & 7 & gene expression profiling \\
4 & 62/M & OD & Keratoplasty for corneal opacity & 7 & gene expression profiling \\
5 & 21/M & OS & Ocular trauma & 7 & gene expression profiling \\
\hline
\end{tabular}

$\mathrm{F}=$ female; $\mathrm{M}=$ male

ayears between the first and the second corneal transplantation 
Table 2 Donor Information

\begin{tabular}{llllll}
\hline Age $(\mathrm{y})$ & Hours $^{\mathrm{a}}$ & Days $^{\mathrm{b}}$ & Cause of Death & Experiment & Samples \\
\hline 19 & 4 & 1 & Motor vehicle accident & SA- $\beta$-Gal staining & whole cornea \\
21 & 5 & 2 & Cardiac arrest & SA- $\beta$-Gal staining & whole cornea \\
25 & 4 & 2 & Traumatic injury & SA- $\beta$-Gal staining & whole cornea \\
21 & 6 & 2 & Motor vehicle accident & gene expression profiling & whole corneal endothelium \\
27 & 7 & 1 & Motor vehicle accident & gene expression profiling & whole corneal endothelium \\
30 & 6 & 1 & Motor vehicle accident & gene expression profiling & whole corneal endothelium \\
31 & 5 & 2 & Motor vehicle accident & gene expression profiling & whole corneal endothelium \\
22 & 4 & 2 & Cardiac arrest & HECEs culture & corneal rims \\
22 & 1 & 1 & Cardiac arrest & HECEs culture & corneal rims \\
22 & 2 & 1 & Motor vehicle accident & HECEs culture & corneal rims \\
25 & 2 & 1 & Cardiac arrest & HECEs culture & corneal rims \\
25 & 2 & 1 & Motor vehicle accident & HECEs culture & corneal rims \\
\hline
\end{tabular}

${ }^{a}$ Number of hours between death and corneal preservation

${ }^{\mathrm{b}} \mathrm{Number}$ of days of corneal preservation in corneal storage medium at $4{ }^{\circ} \mathrm{C}$

senescence $\beta$-galactosidase staining kit (Beyotime Institute of Biotechnology, Shanghai, China) according to the manufacturer's instructions. The staining was visualized and captured using a microscope that was equipped with a digital camera (Eclipse e800; Nikon).

\section{Immunofluorescent staining}

For the immunofluorescent staining, mice corneal tissues were placed with the endothelium side up and fixed with $4 \%$ PFA solution. Then, the samples were incubated overnight at $4{ }^{\circ} \mathrm{C}$ with the primary antibodies (p-ASK1 and p-p38). After washing with PBS, the samples were incubated for $1 \mathrm{~h}$ with FITC conjugated secondary antibody (1:100; Santa Cruz). The stained cells were counterstained with DAPI and viewed under an Eclipse TE2000-U microscope (Nikon, Tokyo, Japan).

\section{Statistical analysis}

All results are expressed as the means \pm SDs. The statistical analyses were performed using SPSS 15.0 software (SPSS, Chicago, IL). For the PCR Array and gene expression profiling study, an independent-Samples $t$-test was performed comparing the two different groups using the Kolmogorov-Smirnov test. For the analysis of the PCR and Western blot results, a One-Way analysis of variance (ANOVA) was performed to compare the groups using the Student-Newman-Keuls test and the Least Significant Difference procedure. $P$ - values of less than 0.05 were considered to be statistically significant.

Information on the Real time PCR, Intracellular reactive oxygen species (ROS) measurement and the detection of mitochondrial ROS, Western blot analysis, and gene expression profiling studies available in the Additional file 1: Materials and Methods.

\section{Results}

\section{Premature senescence in the endothelia of corneal allografts following PKP}

We assessed premature senescence of endothelia using a normal-risk orthotopic mice corneal transplantation model for three times (totally 60 mice). We collected 8 , 11, and 10 corneal grafts for these three times. For each time, four corneal grafts from each of the two groups were used for the detection of staining. That is, one corneal graft was separated into three pieces, and one pieces were used for the staining of the corneal endothelium with trypan blue and alizarin red $S$. The others were used for staining of SA- $\beta-$ Gal and immunohistochemical analysis of 8-OHdG.

The results of the clinical evaluation of mouse corneal graft and corneal endothelium are shown in Fig. 1a and e. The original hexagonal structure of endothelial cells was maintained in the syngeneic group (Fig. 1b). The endothelial cell borders of the corneal grafts from the allogeneic group were opaque, and polykaryocytes were observed in corneal endothelium of the allogeneic group (Fig. 1f). SA- $\beta$-Gal-positive cells were observed in endothelium of the corneal grafts in allogeneic group (Fig. 1g), whereas SA- $\beta$-Gal-positive cells were not observed in endothelium of the corneal grafts in syngeneic group (Fig. 1c). Higher 8-OHdG expression was observed in the nuclei compared to the cytoplasm of the corneal endothelial cells. The percentage $8-\mathrm{OHdG}$ expression was higher in the corneal graft nuclei of allogeneic group (Fig. 1d) than that of syngeneic group (Fig. 1h).

We next compared the expression of $\mathrm{p} 16^{\mathrm{INK} 4 \mathrm{~A}}$, $\mathrm{p} 21^{\mathrm{WAF} 1 / \mathrm{CIP} 1}$ and $\mathrm{p} 53$ proteins in the endothelium of corneal grafts by western blot analysis (Fig. 2). A significant up-regulation of $\mathrm{p} 16^{\mathrm{INK} 4 \mathrm{~A}}, \mathrm{p} 21^{\mathrm{WAF} 1 / \mathrm{CIP} 1}$, and $\mathrm{p} 53$ 

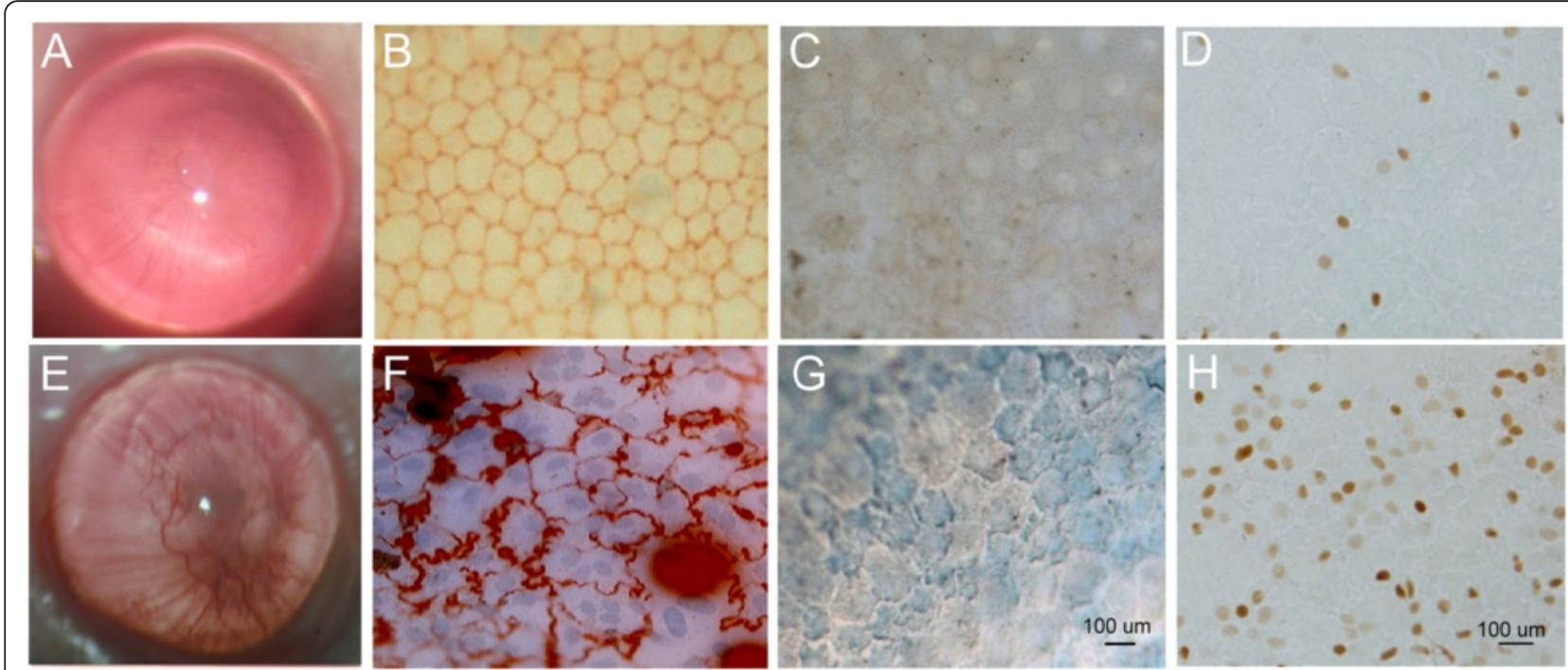

Fig. 1 Premature senescence in mice endothelium of corneal dysfunctional allografts after PKP a Clinical evaluation of mouse corneal graft in syngeneic group (after 4.5 months post grafting); $\mathbf{b}$ Evaluation of endothelium of corneal graft in syngeneic group $(n=4)$ ); $\mathbf{c}$ Representative results of SA- $\beta$-Gal staining on corneal endothelium in syngeneic group; $\mathbf{d}$ Representative results of 8-hydroxydeoxyguanosine (8-OHdG) staining on corneal endothelium in syngenic group; e Clinical evaluation of mouse corneal graft in allogenic group (after 4.5 months post grafting); $\mathbf{f}$ Evaluation of endothelium of corneal graft in allogenic group; $\mathbf{g}$ Representative results of SA- $\beta$-Gal staining on corneal endotheliumin in allogenic group; $\mathbf{h}$ Representative results of $8-\mathrm{OHdG}$ staining on corneal endothelium in allogenic group. Rejection of corneal grafts was observed in allogenic group as opacification of the cornea and new vessel in growth, compared with corneal grafts in syngeneic group e. In syngeneic group, the original hexagonal structure was maintained $\mathbf{b}$ compared with corneal grafts in allogenic group $\mathbf{f}$. The endothelial cell borders of corneal grafts in allogeneic group were not clear, and polykaryocytes were observed in corneal endothelium of allogeneic group $\mathbf{f}$. Compared with corneal grafts in allogeneic group $\mathbf{g}$, SA- $\beta$-Gal positive cells were not observed on corneal endotheliumin in syngeneic group $\mathbf{c}$. This revealed that dysfunctional corneal allografts exhibited characteristics of premature endothelial senescence. Compared with corneal grafts in syngenic group $\mathbf{d}$, the strength and numbers of positive cells of 8-OHdG staining were less than that in allogenic group $\mathbf{h}$

protein expression was observed in the corneal endothelium of allogeneic grafts compared with syngeneic grafts.

Then, the Mouse Oxidative Stress and Antioxidant Defense $\mathrm{RT}^{2}$-PCR Arrays were used to investigate the oxidant-antioxidant imbalance in the endothelium of corneal allografts after PKP. As indicated, a more than two fold change in expression, with $p<0.05$, was considered to be statistically significant. Of the 84 genes assayed, 27 transcripts (32\%) were down-regulated; of these, 17 were expressed at more than two fold lower levels and 11 (13\%) were more highly expressed, as is shown in the three-dimensional profile (Fig. 3a) and the scatter plot (Fig. 3b). Of the genes that were expressed at lower levels, statistical significance was noted for 23 antioxidant genes
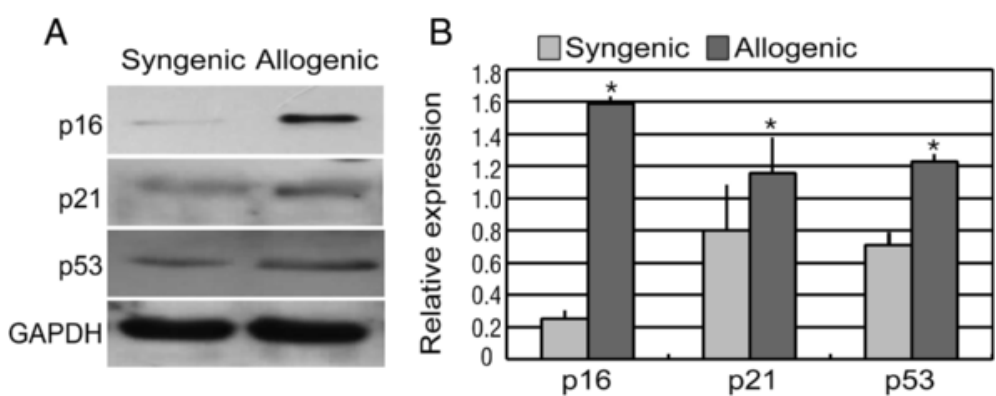

Fig. 2 Up-regulated expression of p16 $6^{\text {INK4A }}, \mathrm{p} 21^{\text {Cip1 }}$ and p53 proteins in mice endothelium of dysfunctional corneal allografts Expression of cell senescence related proteins, p16 $6^{\mathrm{INK} 4 \mathrm{~A}}, \mathrm{p} 21^{\mathrm{Cip} 1 / \mathrm{CDKN} 1 \mathrm{~A}}$ and p53 in mice endothelium of dysfunctional corneal allografts. Changes in protein expression as determined by Western blot. $\mathbf{a}$ data from the gels; $\mathbf{b}$ normalization to GAPDH. For each sample, the relative abundance of the protein of interest is determined by calculating the ratio of the intensity of the signal for the protein of interest to that of the normalization control GAPDH. Band densities determined by ImageJ software and compared with syngenic group. Expression of p16 ${ }^{\text {INK4A }}$, p2 $1^{\text {Cip1/CDKN1A }}$ and p53 were higher in the corneal endothelium of allogenic group than in the syngenic group ( $t$-test, $P<0.05, n=3$ ). Significant differences between the corneal endothelium tissue in syngenic and allogenic groups are indicated by an asterisk $(* P<0.05)$ 


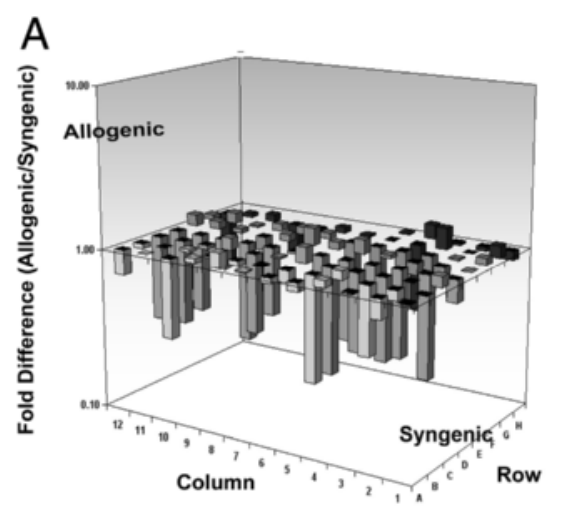

B
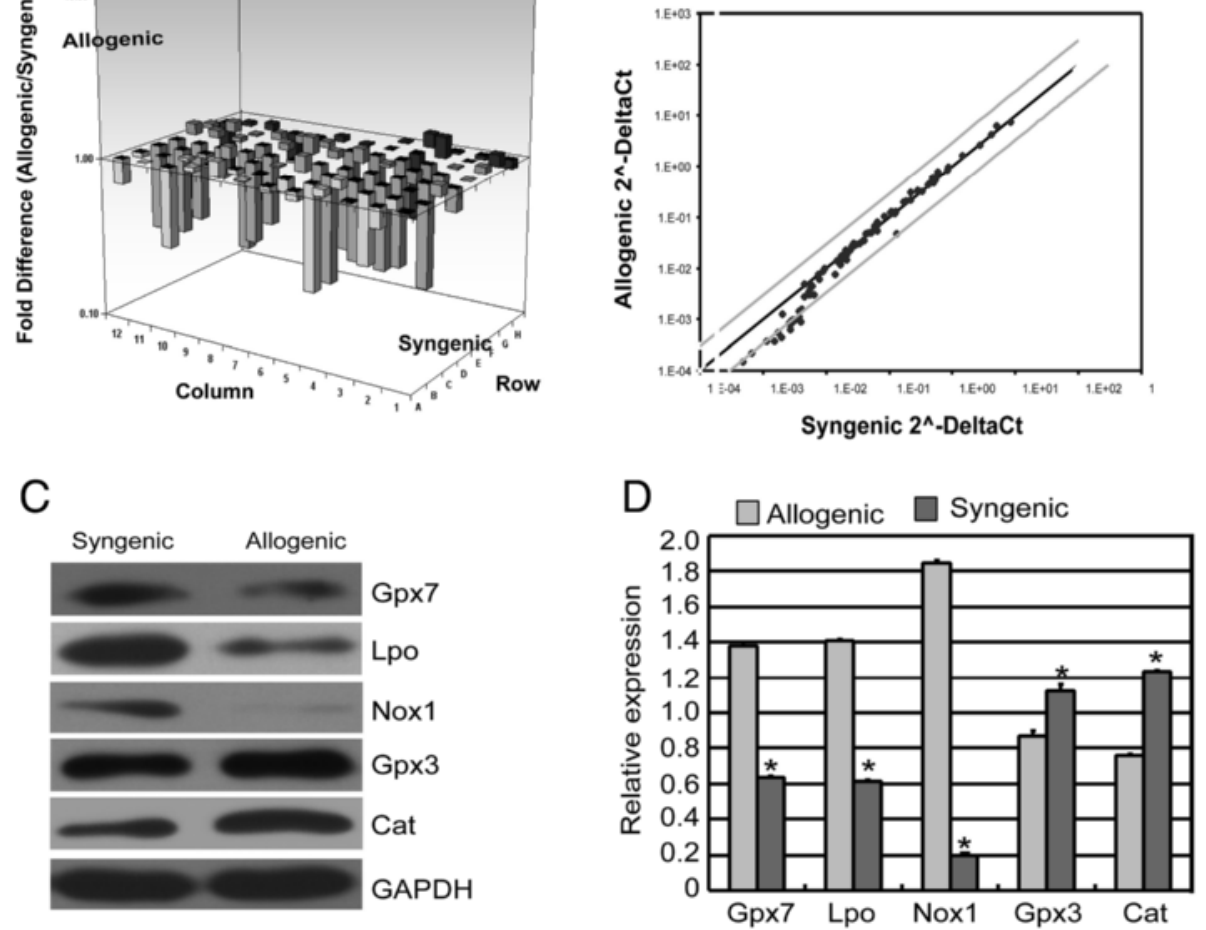

Fig. 3 Oxidant-Antioxidant Imbalance in Mice Corneal Endothelium of Dysfunctional Allografts a Three-dimensional profile of Mouse Oxidative Stress and Antioxidant Defense RT ${ }^{2}$-PCR Arrays. $\mathbf{b}$ Scatter plot of expression differences among genes related to the oxidative stress and antioxidant defense. $\mathbf{c}$ and $\mathbf{d}$ Semiquantitative Western blot analyses were conducted to determine the relative protein level of the five genes found by PCR array analysis to be expressed at significantly different levels in corneal endothelium of allogenic and syngenic corneal grafts. Fig. 3c shows representative blots for each down-expressed protein and Fig. $3 \mathbf{d}$ shows representative blots for each up-expressed protein and the corresponding GAPDH bands. The syngenic group was used as control. For each sample, the relative abundance of the protein of interest is determined by calculating the ratio of the intensity of the signal for the protein of interest to that of the normalization control GAPDH. Band densities determined by ImageJ software and compared with syngenic group. Three additional experiments achieved equivalent results. Data are means $\pm \mathrm{SD}(n=3)$. All means marked with * $(t$-test, $P<0.05)$ are significantly different from the control

(Table 3). The information for the more highly expressed genes is given in Table 4. The genes encoding Glutathione peroxidase 7 (Gpx7), Lactoperoxidase (Lpo) and NADPH oxidase 1 (Nox1) were expressed at 4.48-fold, 4.32-fold and 4.14-fold lower levels, respectively, in allogenic corneal endothelium compared with syngenic corneal endothelium.

In the endothelium of allogenic corneal samples, Gpx7, Lpo, and Nox1 were expressed at 2.22-fold, 2.38fold and 9.10-fold lower levels, respectively, relative to the endothelium in syngenic corneal samples by Western blot analyses (Fig. 3). In the endothelium of allogenic corneal samples, Gpx3 and Cat were expressed at 1.17-fold and 1.58-fold higher levels, respectively, than in the endothelium in the syngenic corneal samples. Then, we showed the results of the ROS accumulation and activation of ASK1/p38 signal pathway in mouse model in Fig. 4. The elevated ROS levels may be the results of the oxidant-antioxidant imbalance.
Representative results of SA- $\beta$-Gal staining on human corneal allografts and in normal human corneal endothelium were shown in Fig. 5-a and b. Compared with normal human corneal endothelium, more SA- $\beta$-Gal positive cells were observed on corneal endothelium in corneal allograft after PKP. These results were consistent with that in the mice model. The result of gene expression profilling was shown as the scatterplot in Fig. 5-c. The scatterplot is a visualization that is useful for assessing the variation between endothelium in corneal allografts (Y-axis) and in normal human corneal endothelium (Xaxis). Microarray-based GO analysis of differentially expressed genes on endothelium between corneal allograft after PKP and normal human corneal endothelium was shown in Fig. 5-d (the most significantly down-regulated genes) and Fig. 5-e (the most significantly up-regulated genes). The three GO classifications, molecular function (MF), biological process (BP), and cellular component (CC), were evaluated separately and the significant terms of all ontologies are shown. 
Table 3 Genes down-regulated in endothelium of mice dysfunctional corneal allografts relative to syngenic control as detected by PCR array

\begin{tabular}{|c|c|c|c|}
\hline Gene description & Symbol & Fold regulation & $P$ \\
\hline \multicolumn{4}{|l|}{ Antioxidant } \\
\hline \multicolumn{4}{|l|}{ Glutathione Peroxidases (Gpx) } \\
\hline Glutathione peroxidase 5 & Gpx5 & -3.18 & 0.1479 \\
\hline Glutathione peroxidase 6 & Gpx6 & -3.05 & 0.0021 \\
\hline Glutathione peroxidase 7 & Gpx7 & -4.48 & 0.0017 \\
\hline \multicolumn{4}{|l|}{ Peroxiredoxins (TPx) } \\
\hline Peroxiredoxin 4 & $\operatorname{Prdx} 4$ & -1.22 & 0.0478 \\
\hline \multicolumn{4}{|l|}{ Other Peroxidases } \\
\hline Lactoperoxidase & Lpo & -4.32 & 0.0007 \\
\hline Prostaglandin-endoperoxide synthase 2 & Ptgs2 & -1.43 & 0.0011 \\
\hline Recombination activating gene 2 & Rag2 & -3.00 & 0.0058 \\
\hline Thyroid peroxidase & Tpo & -2.64 & 0.0016 \\
\hline \multicolumn{4}{|l|}{ Other Antioxidants } \\
\hline Nucleoredoxin & Nxn & -1.19 & 0.0105 \\
\hline \multicolumn{4}{|l|}{ ROS Metabolism } \\
\hline \multicolumn{4}{|l|}{ Superoxide Metabolism } \\
\hline Cytochrome b-245, alpha polypeptide & Cyba & -1.43 & 0.0122 \\
\hline Neutrophil cytosolic factor 2 & Ncf2 & -1.87 & 0.0045 \\
\hline NADPH oxidase 1 & Nox1 & -4.14 & 0.0052 \\
\hline NADPH oxidase 4 & Nox4 & -1.58 & 0.022 \\
\hline NADPH oxidase activator 1 & Noxa1 & -3.11 & 0.1457 \\
\hline NADPH oxidase organizer 1 & Noxol & -1.63 & 0.0349 \\
\hline RecQ protein-like 4 & Recq14 & -1.83 & 0.0016 \\
\hline \multicolumn{4}{|l|}{ Other genes involved in ROS Metabolism } \\
\hline Interleukin 19 & $\| 19$ & -3.37 & 0.0001 \\
\hline Interleukin 22 & $\| 22$ & -3.41 & 0.0008 \\
\hline \multicolumn{4}{|l|}{ Oxidative stress responsive genes } \\
\hline Dual oxidase 1 & Duox1 & -2.65 & 1.80E-05 \\
\hline Eosinophil peroxidase & Epx & -4.46 & 2.00E-04 \\
\hline Myeloperoxidase & Mpo & -3.49 & 0.0041 \\
\hline $\begin{array}{l}\text { Membrane protein, palmitoylated } 4 \\
\text { (MAGUK p55 subfamily member 4) }\end{array}$ & Mpp4 & -3.11 & 0.0043 \\
\hline $\begin{array}{l}\text { Nudix (nucleoside diphosphate linked } \\
\text { moiety X)-type motif } 15\end{array}$ & Nudt15 & -1.18 & 0.0106 \\
\hline $\begin{array}{l}\text { Uncoupling protein } 3 \text { (mitochondrial, } \\
\text { proton carrier) }\end{array}$ & Uср3 & -1.58 & 0.0088 \\
\hline \multicolumn{4}{|l|}{ Oxygen transporters } \\
\hline Hemoglobin, theta $1 \mathrm{~A}$ & $\mathrm{Hbqla}$ & -3.13 & 0.0511 \\
\hline Myoglobin & $\mathrm{Mb}$ & -3.44 & 0.0604 \\
\hline Xin actin-binding repeat containing 1 & Xirp1 & -3.13 & 0.0003 \\
\hline
\end{tabular}

Oxidative stress, elevated ROS levels, the up-regulation of CDK inhibitors and ROS-mediated p16 ${ }^{\text {INK4A }}$ up-regulation in HCECs occur via the ASK1-p38 MAPK pathway

Given that the oxidant-antioxidant imbalance was involved in endothelium of corneal allografts, we developed an in vitro experimental model using $\mathrm{H}_{2} \mathrm{O}_{2}$
Table 4 Genes up-regulated in endothelium of mice dysfunctional corneal allografts relative to syngenic control as detected by PCR array

\begin{tabular}{|c|c|c|c|}
\hline Gene description & Symbol & Fold regulation & $P$ \\
\hline \multicolumn{4}{|l|}{ Antioxidant } \\
\hline \multicolumn{4}{|l|}{ Glutathione Peroxidases (Gpx) } \\
\hline Glutathione peroxidase 3 & Gpx3 & 1.17 & 0.0118 \\
\hline \multicolumn{4}{|l|}{ Other Peroxidases } \\
\hline Glutathione reductase & Gsr & 1.25 & 0.0079 \\
\hline Catalase & Cat & 1.24 & 0.0033 \\
\hline Adenomatosis polyposis coli & $\mathrm{Apc}$ & 1.11 & 0.0144 \\
\hline Peroxiredoxin 6, pseudogene 1 & Prdx6-ps1 & 1.17 & 0.0051 \\
\hline Tropomodulin 1 & Tmod1 & 1.37 & 0.0004 \\
\hline \multicolumn{4}{|l|}{ ROS Metabolism } \\
\hline \multicolumn{4}{|l|}{ Superoxide Metabolism } \\
\hline $\begin{array}{l}\text { Stearoyl-Coenzyme A } \\
\text { desaturase } 1\end{array}$ & Scd1 & 1.09 & 0.0385 \\
\hline \multicolumn{4}{|l|}{$\begin{array}{l}\text { Oxidative stress responsive } \\
\text { genes }\end{array}$} \\
\hline $\begin{array}{l}\text { Isocitrate dehydrogenase } 1 \\
(\mathrm{NADP}+) \text {, soluble }\end{array}$ & Idh1 & 1.19 & 0.0016 \\
\hline $\begin{array}{l}\text { Protein phosphatase } 1, \\
\text { regulatory (inhibitor) subunit } \\
15 b\end{array}$ & Ppp1r15b & 1.22 & 0.0048 \\
\hline Peroxiredoxin 2 & $\operatorname{Prd} \times 2$ & 1.29 & 0.0114 \\
\hline \multicolumn{4}{|l|}{ Oxygen transporters } \\
\hline $\begin{array}{l}\text { Solute carrier family } 38, \\
\text { member } 1\end{array}$ & Slc38a1 & 1.11 & 0.0462 \\
\hline
\end{tabular}

treatment to simulate a state of oxidative stress. Primary culture of human corneal endothelial cells with generic function associated markers such as $\mathrm{Na}^{+} \mathrm{K}^{+}$ATPase and ZO-1 as well as PRDX6 were characterized. Intracellular ROS and mitochondria ROS accumulation were compared. ROS generation was observed in HCECs 60 minutes following treatment with $100 \mu \mathrm{M} \mathrm{H} \mathrm{H}_{2} \mathrm{O}_{2}$ (Fig. 6a-i and 6a-ii). The data indicate that intracellular ROS levels are much higher in HCECs following $\mathrm{H}_{2} \mathrm{O}_{2}$ treatment than in untreated cells. SA- $\beta-\mathrm{Gal}$ positivity was also observed in HCECs after 60 minutes of treatment with $100 \mu \mathrm{M} \mathrm{H}_{2} \mathrm{O}_{2}$ (Fig. 6a-iii and 6a-iv). To determine whether ROS production is enhanced in the mitochondria of HCECs following $\mathrm{H}_{2} \mathrm{O}_{2}$ treatment, the localization of MitoTracker Green FM with MitoSOX red was performed. As revealed by the localization of Mito Tracker Green (Fig. 6b-ii and 6a-v), $\mathrm{H}_{2} \mathrm{O}_{2}$ treated cells exhibited red fluorescence in mitochondria, indicating increased mitochondrial ROS production (Fig. 6b-iv) compared with the control HCECs (Fig. 6b-i).

Inhibitors of cyclin-dependent kinases (CDKs) are considered to play critical roles in cell cycle arrest and 


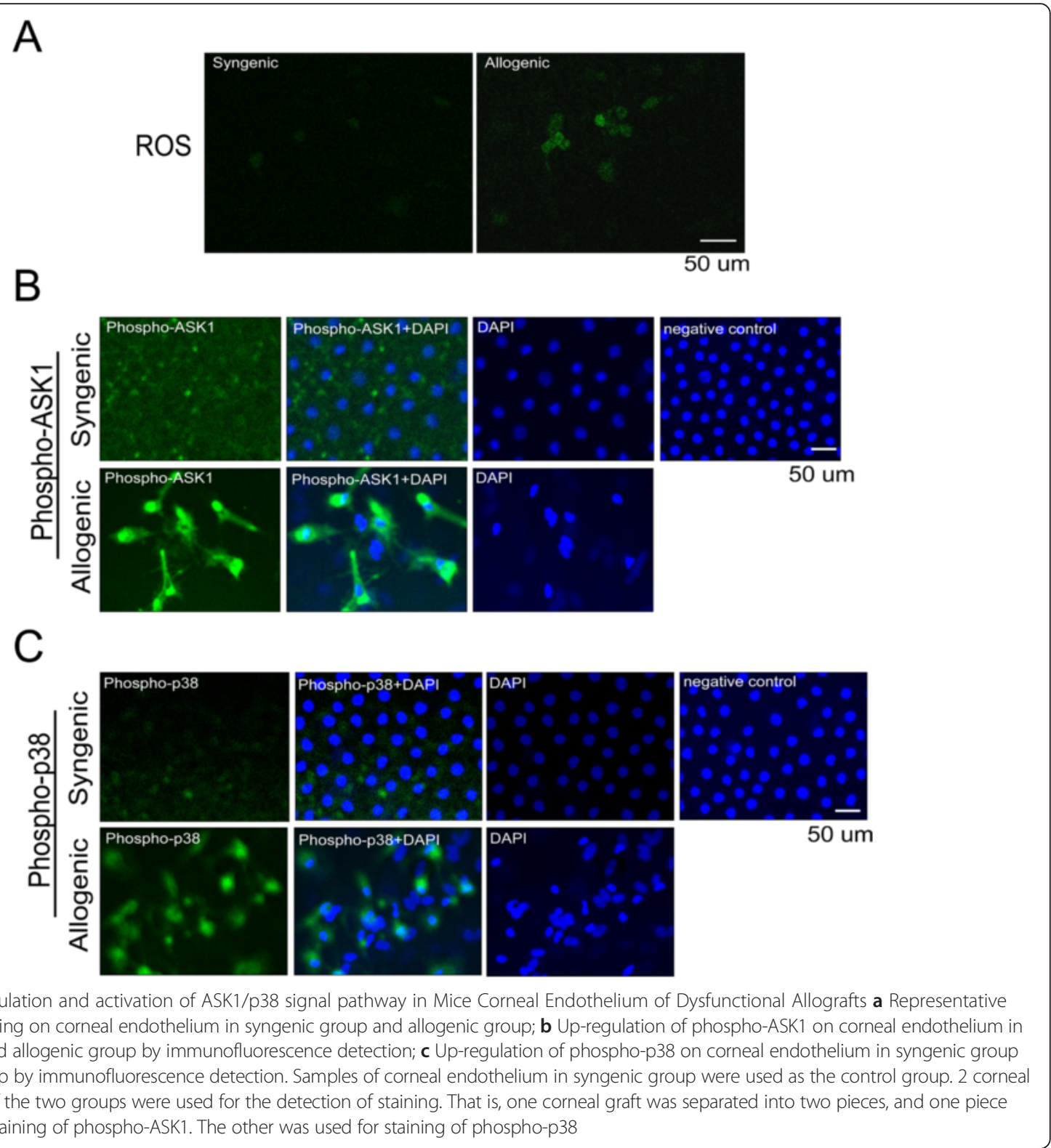

premature senescence $[8,26]$. We therefore investigated the effects of ROS on the levels of CDK inhibitors in HCECs, including $\mathrm{p} 16^{\mathrm{INK} 4 \mathrm{~A}}, \mathrm{p} 21^{\mathrm{cip} 1}$, and $\mathrm{p} 27^{\mathrm{kip} 1}$. At 2 hours after $100 \mu \mathrm{M} \mathrm{H} \mathrm{H}_{2} \mathrm{O}_{2}$ treatment, a brief upregulation of $\mathrm{p} 16^{\mathrm{INK} 4 \mathrm{~A}}, \mathrm{p} 21^{\mathrm{cip} 1}$, and $\mathrm{p} 27^{\mathrm{kip} 1}$ mRNA was observed in HCECs (Fig. 6c). We also detected the protein expression levels of $\mathrm{p} 16^{\mathrm{INK} 4 \mathrm{~A}}, \mathrm{p} 21^{\mathrm{cip} 1}$, and $\mathrm{p} 27^{\text {kip1 }}$ by western blot analysis, as is shown in Fig. $6 \mathrm{~d}$. When the HCECs were exposed to $100 \mu \mathrm{M} \mathrm{H}_{2} \mathrm{O}_{2}$, the levels of $\mathrm{p} 16^{\mathrm{INK} 4 \mathrm{~A}}, \mathrm{p} 21^{\mathrm{cip} 1}$, and $\mathrm{p} 27^{\text {kip1 }}$ protein expression were elevated, and this up-regulation persisted from 2 to 6 hours post- $\mathrm{H}_{2} \mathrm{O}_{2}$ treatment.

To address whether $\mathrm{H}_{2} \mathrm{O}_{2}$-induced HCECs senescence is related to the activity of ASK1-p38 MAPK pathway, the protein levels of ASK1 or phosphorylated ASK1 was measured by Western blot analysis. p38 MAPK activation was then compared between the $\mathrm{H}_{2} \mathrm{O}_{2}$-treated and untreated HCECs in vitro. Fig. 7a presents representative the results of the Western blot studies. The phosphorylation levels of ASK1 and p38 MAPK significantly increased in HCECs following $\mathrm{H}_{2} \mathrm{O}_{2}$ treatment. We also used siRNA that specifically silences ASK1 and SB203580, a widely used p38 inhibitor, to investigate the molecular mechanisms that underlie $\mathrm{H}_{2} \mathrm{O}_{2}$-induced endothelial cell senescence in cultured HCECs. By Western blotting analysis, we found that the expression of ASK1 was down-regulated after transfection with ASK1siRNA and ASK1-siRNA also decreased the activation of 


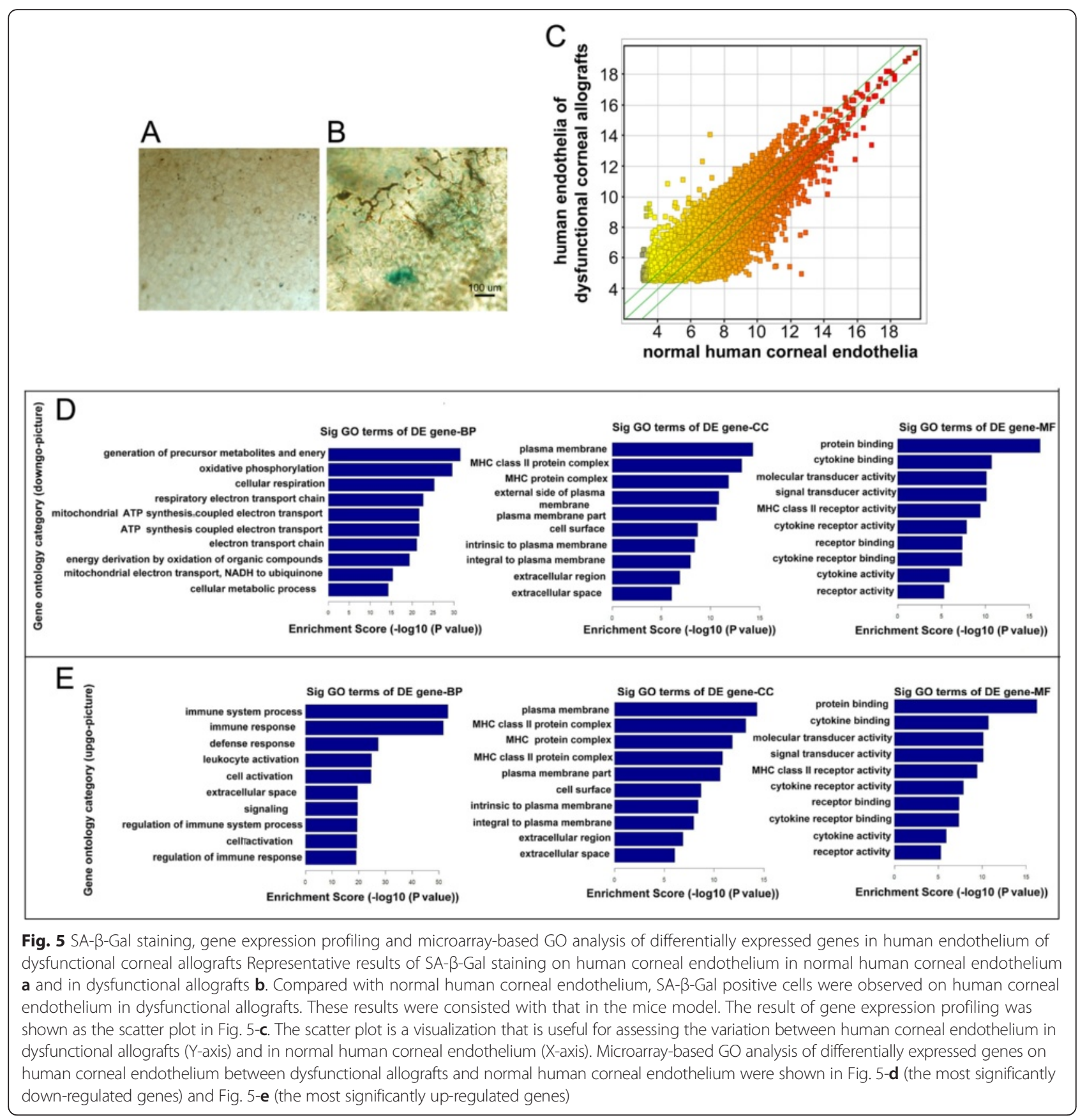

MAKP in HCECs (Fig. 7b). By the pharmacological inhibitor SB203580, the expression of p38 was downregulated in HCECs treated with $\mathrm{H}_{2} \mathrm{O}_{2}$ (Fig. 7c).

To address whether p38 signaling is required for senescence in response to ROS accumulation in HCECs, we showed the data of the effect of SB203580 on cell senescence in Fig. 8. We found that the ROS levels and the strength of SA- $\beta$-Gal staining were decreased after SB203580 treatment (Fig. 8-a and 8-b). We also detected the expression of cell senescence related proteins, including p16 ${ }^{\mathrm{INK} 4 \mathrm{~A}}, \mathrm{p} 27^{\mathrm{kip} 1}$ and p53. As shown in Fig. 8-c, the expression of the three proteins was down-regulated after treatment with SB203580 in HCECs, compared with no treatment of SB203580. These results imply that the ASK1-p38 MAPK pathway may be involved in ROSinduced CECs senescence.

\section{Discussion}

In this study, we report a studying on penetrating keratoplasty and in particular the potential mechanisms behind post-operative failure (for example, corneal opacity and the role of the endothelium). We use a 


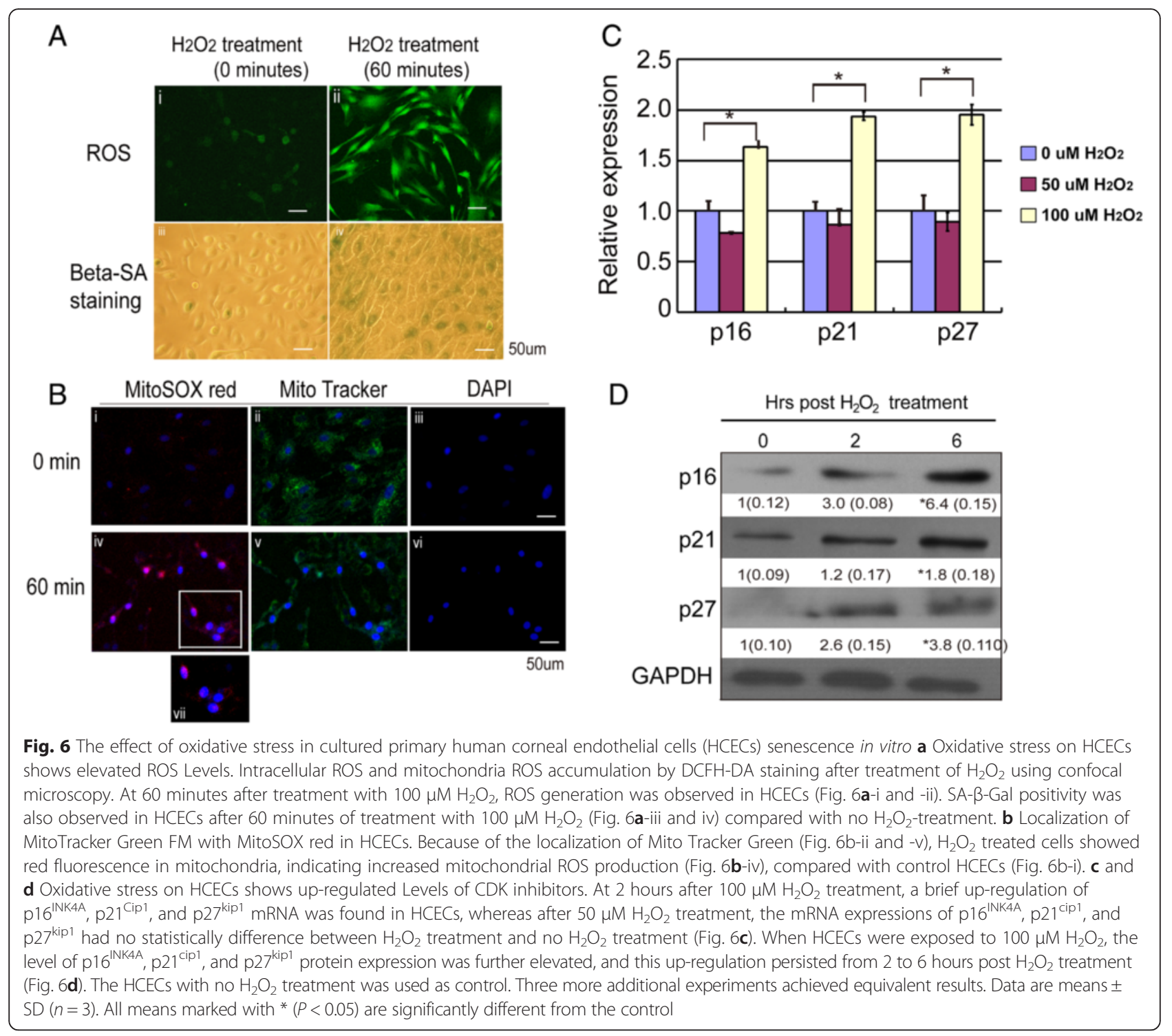

combination of descriptive data from human PKP samples, together with a mouse model (syngeneic versus allogeneic corneal transplantations) and some cell work in vitro with human HCECs treated with peroxide.

In the context of PKP, premature senescence is important clinically not only because aging alters corneal function but also because old corneas perform poorly when transplanted. The endothelium is a major determinant of graft survival. Since stress might accelerate ageing changes, it will be instructive to understand the mechanisms of premature senescence in HECEs. HCECs are arrested in the G1 phase of the cell cycle and given the correct culture medium, HCECs can be grown for many population doublings in culture [27]. We previously reported an age-related increase in $\mathrm{p} 16^{\mathrm{INK} 4 \mathrm{~A}} \mathrm{ex}-$ pression in normal HCECs in vivo [28] and in the senescence accelerated mouse (SAM), indicating that the increased expression of $\mathrm{p} 16^{\mathrm{INK} 4 \mathrm{~A}}$ is an age-dependent phenomenon in the corneal endothelium [29]. We also observed that the high expression of $\mathrm{p} 16^{\mathrm{INK} 4 \mathrm{~A}}$ and low expression of Bmil are associated with cellular senescence of HCECs [30]. Other groups also investigate the characterisation of cellular senescence mechanisms in HCECs [27]. The above studies reported the common aging phenotype and molecular mechansims of normal HCECs.

The accumulation of SA- $\beta-$ Gal is suggested to be a specific marker of cell senescence [31, 32] and 8-OHdG is the most frequently detected and studied biomarker of ROS for cancer, atherosclerosis and diabetes [33]. In the present study, we found the elevated level of 8-OHdG, suggesting the existence of ROS in corneal endothelium after PKP. Furthermore, the expressions of $\mathrm{p} 16^{\mathrm{INK} 4 \mathrm{a}}$, $\mathrm{p} 21^{\mathrm{WAF} 1 / \mathrm{CIP} 1}$ and $\mathrm{p} 53$ proteins in corneal endothelium 

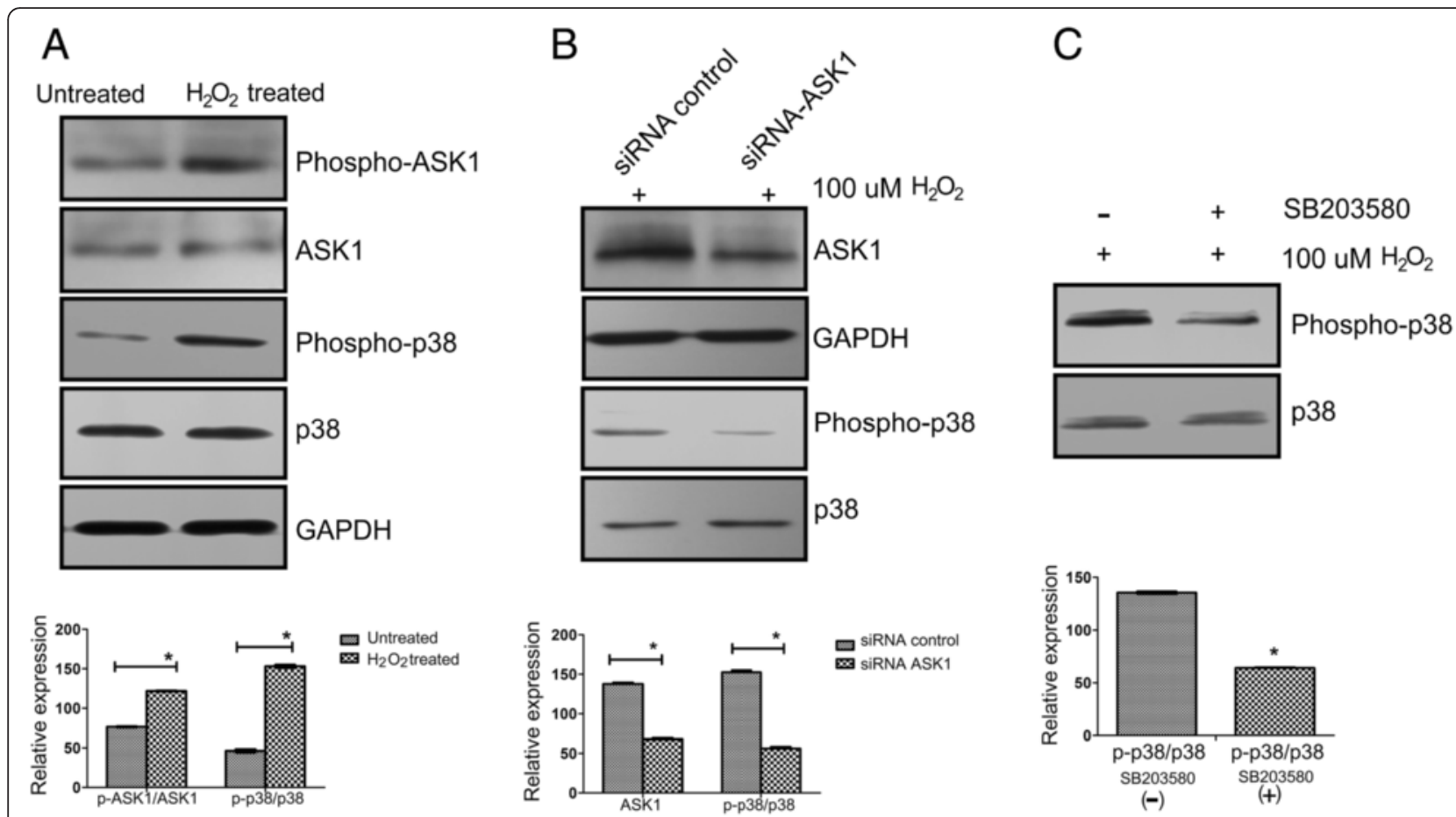

Fig. 7 ASK1/p38 signaling is activated in cultured HCECs in vitro. a The protein level of ASK1 or phosphorylated ASK1 was measured by Western blot and then the activation of p38 MAPK was also compared with or without $\mathrm{H}_{2} \mathrm{O}_{2}$ treatment of HCECs in vitro. Top panel: shows the representative data from the gels; bottom panel: the results normalized to GAPDH. GAPDH served as the loading control. The HCECs with no $\mathrm{H}_{2} \mathrm{O}_{2}$ treatment was used as control. Three more additional experiments achieved equivalent results. Data are means \pm SD $(n=3)$. All means marked with * $(t$-test, $P<0.05)$ are significantly different from the control. b siRNA ASK1 decreased $\mathrm{H}_{2} \mathrm{O}_{2}$-induced p38 activation. HCECs were transfected with 150 nM ASK1 siRNA and control siRNA, and $24 \mathrm{~h}$ later, cells were treated with $100 \mu \mathrm{M} \mathrm{H}_{2} \mathrm{O}_{2}$ for $4 \mathrm{~h}$. The protein expression was measured by Western Blot. Top panel: shows the representative data from the gels; bottom panel: the results normalized to GAPDH. GAPDH served as the loading control. Three more additional experiments achieved equivalent results. Data are means $\pm \mathrm{SD}(n=3)$. All means marked with $*(P<0.05)$ are significantly different from the control. c p38 signaling is required for the response to ROS in cultured HCECs in vitro. HCECs were pretreated with or without SB203580 (10 $\mu \mathrm{M})$ for $2 \mathrm{~h}$ and then coincubated with $100 \mu \mathrm{M} \mathrm{H}_{2} \mathrm{O}_{2}$ for $4 \mathrm{~h}$. The protein levels were measured by Western blot assays. Top panel: shows the representative data from the gels; bottom panel: the results normalized to GAPDH. GAPDH served as the loading control. HCECs treated without SB203580 was used as control. Three more additional experiments achieved equivalent results. Data are means \pm SD $(n=3)$. All means marked with * $(P<0.05)$ are significantly different from the control

of allogeneic grafts were correlated with the accumulation of SA- $\beta$-Gal and 8 -OHdG, and their expressions were consistent with their induction as a function of cell aging.

ROS play a role in cellular functions including signal transduction at normal concentrations [34]. But an imbalance between generation of ROS and capacity of antioxidants to neutralize ROS can result in disruption of cellular redox status, leading to oxidative stress [35]. Several studies have suggested that low doses of $\mathrm{H}_{2} \mathrm{O}_{2}$ promote cell proliferation, whereas high levels of ROS can induce DNA damage and trigger cell aging, eventually causing cells to enter senescence prematurely $[36,37]$. Thus, we developed an in vitro experimental model using treatment of $\mathrm{H}_{2} \mathrm{O}_{2}$ to simulate cells in a state of oxidative stress. In this study, the dose of $\mathrm{H}_{2} \mathrm{O}_{2}$ that is being used was $100 \mu \mathrm{M}$. Low concentrations of $\mathrm{H}_{2} \mathrm{O}_{2}$ (less than $10 \mu \mathrm{M}$ ) were found to stimulate cell proliferation in fibroblasts [38]. Whereas intermediate concentrations of $\mathrm{H}_{2} \mathrm{O}_{2}(10 \sim 150 \mu \mathrm{M})$ caused cell growth arrest and senescence $[4,39]$.

For PKP, the cumulative burden of injury may exhaust the ability of corneal endothelial cells to repair and remodel to maintain tissue integrity. PKP may represent a final common pathway that greatly accelerated by the special stresses on the transplant, such as aging, nonimmune injury, and rejection. This is more a result of endothelial deterioration for cornea. In our study, the data suggest a ROS/p38 driver of senescence in corneal syngeneic transplants. The reasons for such transplant generate ROS and rigger senescence may be age-related diseases before the transplant, peri-transplant injury or rejection. This is a key question both to understand the significance of our results and also to start to understand why some PKP cases fail. To test this properly would require a quite complex mouse interventional study (p38 inhibition during transplantation), we do attempt a cell line model system to test the causality. Using $100 \mu \mathrm{M}$ 


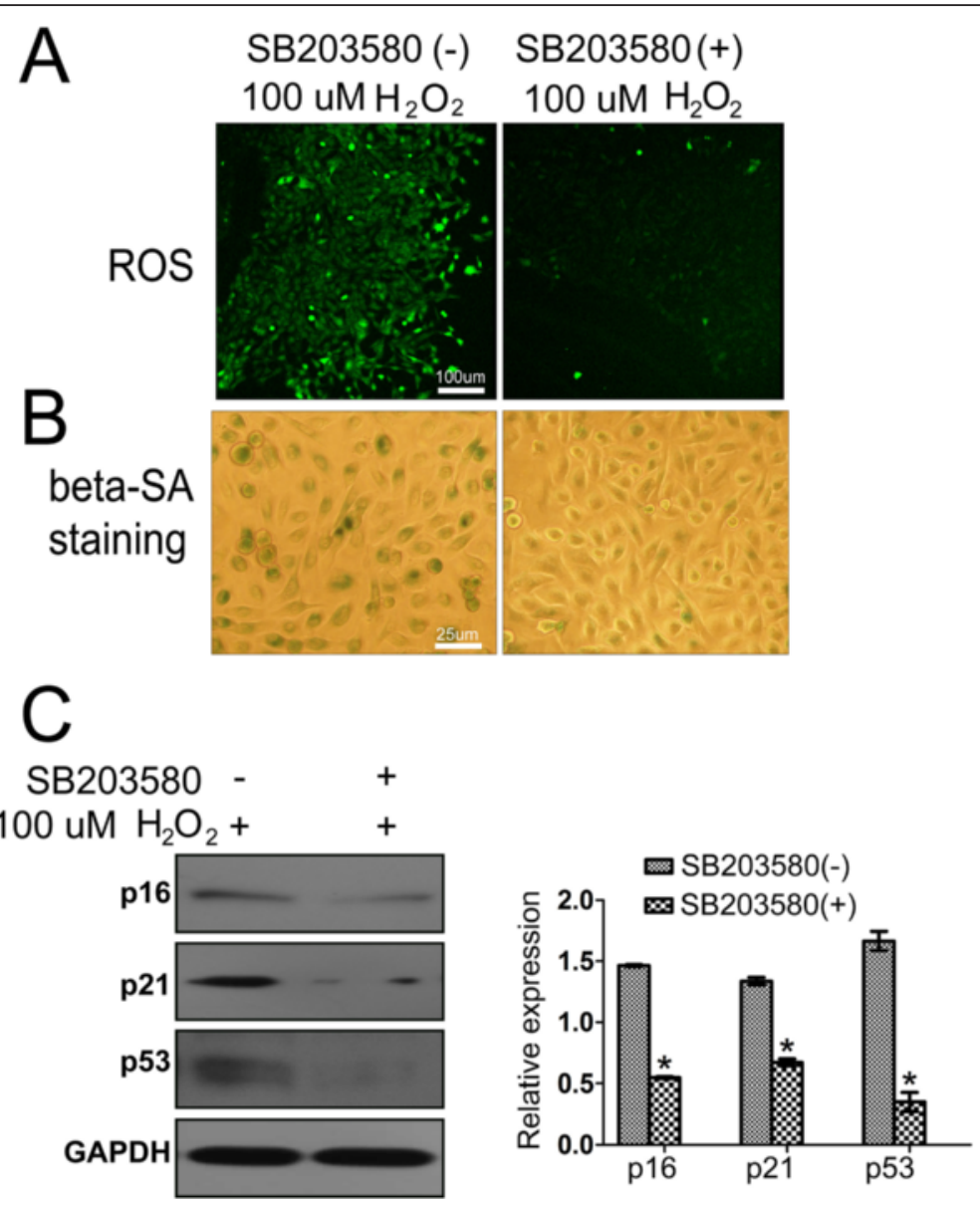

Fig. 8 ASK1/p38 signaling is required for the response to ROS in cultured HCECs in vitro. a The level of ROS was measured and compared with or without SB203580 treatment of HCECs under $\mathrm{H}_{2} \mathrm{O}_{2}$ induced oxidative stress conditions in vitro. Bar $=100 \mu \mathrm{m}$. The HCECs with no SB203580 treatment was used as control. Three more additional experiments achieved equivalent results. $\mathbf{b}$ SA-beta-Gal staining was performed and compared with or without SB203580 treatment of HCECs under $\mathrm{H}_{2} \mathrm{O}_{2}$ induced oxidative stress conditions in vitro. $\mathrm{Bar}=25 \mu \mathrm{m}$. The HCECs with no SB203580 treatment was used as control. Three more additional experiments achieved equivalent results. c The protein level of p16, p21 and p53 was measured by Western blot and compared with or without SB203580 treatment of HCECs in vitro. Left panel: shows the representative data from the gels; right panel: the results normalized to GAPDH. GAPDH served as the loading control. The HCECs with no SB203580 treatment was used as control. Three more additional experiments achieved equivalent results. Data are means \pm SD $(n=3)$. All means marked with ${ }^{*}(P<0.05)$ are significantly different from the control

peroxide we induce senescence in HCECs, and interestingly show that both ROS markers and SA- $\beta$-Gal elevation can be suppressed using a p38 small molecule inhibitor (Fig. 8). Although there are some obvious concerns regarding the very high peroxide levels we use, these interventional studies do give initial support for the model we suggest.

\section{Conclusions}

In conclusion, our observations indicate an elevation of markers of ROS (both directly and via looking at oxidative defence gene expression), and markers of senescence $\left(\mathrm{SA}-\beta-\mathrm{Gal}\right.$ and proteins such as $\mathrm{p} 16^{\mathrm{INK} 4 \mathrm{a}} / \mathrm{p} 21^{\mathrm{WAF} 1 / \mathrm{CIP} 1 /}$ p53 that are associated with senescence). We also show evidence for activation of the p38MAPK and ASK1 pathway in this situation. These observational data would be consistent with a pathway of $\mathrm{ROS}>\mathrm{p} 38$ / ASK1 > senescence. This in turn suggests a SIPS process taking place in the corneal syngeneic transplants. Our results will give new insights into the molecular pathogenesis of corneal allograft dysfunction, providing future targets for therapeutic intervention.

\section{Additional file}

Additional file 1: Supplemental Materials and Methods. (DOCX 20 kb)

\section{Abbreviations}

HCEC: Human corneal endothelial cells; LKP: Lamellar keratoplasty; PKP: Penetrating keratoplasty; ROS: Reactive oxygen species; SIPS: Stressinduced prematural senescence. 


\section{Competing interests}

The authors declare no conflict of interest.

\section{Author's contributions}

YW (Ye Wang) participated in the conception and design of the study and the critical revision of the manuscript for important intellectual content. XZ and SL contributed the animal model for the study. YW (Yao Wang) and PC contributed the cell culture and treatment for the study. XZ performed the data collection and analysis. YW (Ye Wang) interpreted the data and produced the draft of the manuscript. YW (Ye Wang) obtained funding for the study. All authors read and approved the final version of the manuscript.

\section{Acknowledgements}

This work was supported by the National Natural Science Foundation of China (81370990,81300742 and 30901637), the Shandong Province Natural Science Foundation (BS2012YY030 and BS2013YY013) and the Shandong Provincial Excellent Innovation Team Program.

Received: 15 February 2015 Accepted: 27 January 2016 Published online: 02 February 2016

\section{References}

1. Laule A, Cable MK, Hoffman CE, Hanna C. Endothelial cell population changes of human cornea during life. Arch Ophthalmol. 1978;96(11):2031-5.

2. Bourne WM, Hodge DO, Nelson LR. Corneal endothelium five years after transplantation. Am J Ophthalmol. 1994:118(2):185-96.

3. Prokhorenko VI, Nagy AM, Waschuk SA, Brown LS, Birge RR, Miller RJ. Coherent control of retinal isomerization in bacteriorhodopsin. Science. 2006;313(5791):1257-61.

4. Hori J, Streilein JW. Dynamics of donor cell persistence and recipient cell replacement in orthotopic corneal allografts in mice. Invest Ophthalmol Vis Sci. 2001;42(8):1820-8.

5. [[Lagali L, 2010 \#132], Lagali N, Stenevi U, Claesson M, Fagerholm P, Hanson C, et al. Swedish Society of Corneal S: Donor and recipient endothelial cell population of the transplanted human cornea: a two-dimensional imaging study. Invest Ophthalmol Vis Sci. 2010;51(4):1898-904.

6. Lass JH, Gal RL, Dontchev M, Beck RW, Kollman C, Dunn SP, et al. Donor age and corneal endothelial cell loss 5 years after successful corneal transplantation. Specular microscopy ancillary study results. Ophthalmology. 2008;115(4):627-32. e628.

7. Campisi J. Senescent cells, tumor suppression, and organismal aging: good citizens, bad neighbors. Cell. 2005;120(4):513-22.

8. Collado M, Blasco MA, Serrano M. Cellular senescence in cancer and aging. Cell. 2007:130(2):223-33.

9. Koppelstaetter C, Schratzberger G, Perco P, Hofer J, Mark W, Ollinger R, et al. Markers of cellular senescence in zero hour biopsies predict outcome in renal transplantation. Aging Cell. 2008;7(4):491-7.

10. McGlynn LM, Stevenson K, Lamb K, Zino S, Brown M, Prina A, et al. Cellular senescence in pretransplant renal biopsies predicts postoperative organ function. Aging Cell. 2009;8(1):45-51.

11. Hubbard WJ, Dashti N. Aging and transplantation - a topic for biomedicine or bioethics? Aging Dis. 2012;2(2):181-5

12. Melk A, Schmidt BM, Braun H, Vongwiwatana A, Urmson J, Zhu LF, et al. Effects of donor age and cell senescence on kidney allograft survival. Am J Transplant. 2009;9(1):114-23.

13. Joosten $S A$, van Ham V, Nolan $C E$, Borrias $M C$, Jardine AG, Shiels PG, et al. Telomere shortening and cellular senescence in a model of chronic renal allograft rejection. Am J Pathol. 2003;162(4):1305-12.

14. Herbig U, Ferreira M, Condel L, Carey D, Sedivy JM. Cellular senescence in aging primates. Science. 2006;311(5765):1257.

15. Joyce NC, Zhu CC, Harris DL. Relationship among oxidative stress, DNA damage, and proliferative capacity in human corneal endothelium. Invest Ophthalmol Vis Sci. 2009;50(5):2116-22.

16. Joyce NC, Harris DL, Zhu CC. Age-related gene response of human corneal endothelium to oxidative stress and DNA damage. Invest Ophthalmol Vis Sci. 2011:52(3):1641-9.

17. Konomi K, Joyce NC. Age and topographical comparison of telomere lengths in human corneal endothelial cells. Mol Vis. 2007:13:1251-8.

18. Schroeter H, Boyd C, Spencer JP, Williams RJ, Cadenas E, Rice-Evans C. MAPK signaling in neurodegeneration: influences of flavonoids and of nitric oxide. Neurobiol Aging. 2002;23(5):861-80.
19. Ichijo H, Nishida E, Irie K, ten Dijke P, Saitoh M, Moriguchi T, et al. Induction of apoptosis by ASK1, a mammalian MAPKKK that activates SAPKJJNK and p38 signaling pathways. Science. 1997;275(5296):90-4.

20. Yokoi T, Fukuo K, Yasuda O, Hotta M, Miyazaki J, Takemura Y, et al. Apoptosis signal-regulating kinase 1 mediates cellular senescence induced by high glucose in endothelial cells. Diabetes. 2006;55(6):1660-5.

21. Soga M, Matsuzawa A, Ichijo H. Oxidative Stress-Induced Diseases via the ASK1 Signaling Pathway. Int J Cell Biol. 2012;2012:439587.

22. Cursiefen C, Cao J, Chen L, Liu Y, Maruyama K, Jackson D, et al. Inhibition of hemangiogenesis and lymphangiogenesis after normal-risk corneal transplantation by neutralizing VEGF promotes graft survival. Invest Ophthalmol Vis Sci. 2004;45(8):2666-73.

23. Taylor MJ, Hunt CJ. Dual staining of corneal endothelium with trypan blue and alizarin red S: importance of $\mathrm{pH}$ for the dye-lake reaction. Br J Ophthalmol. 1981:65(12):815-9.

24. Mimura T, Joyce NC. Replication competence and senescence in central and peripheral human corneal endothelium. Invest Ophthalmol Vis Sci. 2006;47(4):1387-96.

25. Mishima K, Handa JT, Aotaki-Keen A, Lutty GA, Morse LS, Hjelmeland LM. Senescence-associated beta-galactosidase histochemistry for the primate eye. Invest Ophthalmol Vis Sci. 1999;40(7):1590-3.

26. Serrano M, Hannon GJ, Beach D. A new regulatory motif in cell-cycle control causing specific inhibition of cyclin D/CDK4. Nature. 1993;366(6456):704-7.

27. Sheerin AN, Smith SK, Jennert-Burston K, Brook AJ, Allen MC, Ibrahim B, et al. Characterization of cellular senescence mechanisms in human corneal endothelial cells. Aging Cell. 2012;11(2):234-40.

28. Song Z, Wang Y, Xie L, Zang X, Yin H. Expression of senescence-related genes in human corneal endothelial cells. Mol Vis. 2008;14:161-70.

29. Xiao X, Wang Y, Gong H, Chen P, Xie L. Molecular evidence of senescence in corneal endothelial cells of senescence-accelerated mice. Mol Vis. 2009;15:747-61.

30. Wang $Y$, Zang $X$, Chen P. High expression of p16INK4a and low expression of Bmi1 are associated with endothelial cellular senescence in the human cornea. Mol Vis. 2012;18:803-15.

31. Bodnar AG, Ouellette M, Frolkis M, Holt SE, Chiu CP, Morin GB, et al. Extension of life-span by introduction of telomerase into normal human cells. Science. 1998:279(5349):349-52.

32. Sigal SH, Rajvanshi P, Gorla GR, Sokhi RP, Saxena R, Gebhard Jr DR, et al. Partial hepatectomy-induced polyploidy attenuates hepatocyte replication and activates cell aging events. Am J Physiol. 1999;276(5 Pt 1):G1260-72.

33. Wu LL, Chiou CC, Chang PY, Wu JT. Urinary 8-OHdG: a marker of oxidative stress to DNA and a risk factor for cancer, atherosclerosis and diabetics. Clin Chim Acta. 2004;339(1-2):1-9.

34. Kamsler A, Daily D, Hochman A, Stern N, Shiloh Y, Rotman G, et al. Increased oxidative stress in ataxia telangiectasia evidenced by alterations in redox state of brains from Atm-deficient mice. Cancer Res. 2001;61 (5):1849-54.

35. Rhee SG. Cell signaling. $\mathrm{H}_{2} \mathrm{O} 2$, a necessary evil for cell signaling. Science. 2006:312(5782):1882-3.

36. Bennett MR. Reactive oxygen species and death: oxidative DNA damage in atherosclerosis. Circ Res. 2001:88(7):648-50.

37. Cooke MS, Evans MD, Dizdaroglu M, Lunec J. Oxidative DNA damage: mechanisms, mutation, and disease. FASEB J. 2003;17(10):1195-214.

38. Kim BY, Han MJ, Chung AS. Effects of reactive oxygen species on proliferation of Chinese hamster lung fibroblast (V79) cells. Free Radic Biol Med. 2001:30(6):686-98.

39. Taniyama Y, Griendling KK. Reactive oxygen species in the vasculature: molecular and cellular mechanisms. Hypertension. 2003:42(6):1075-81. 